\title{
Entrepreneurship Development Programme with Reference To Small Enterprises in Nepal
}

Bir Bahadur karki

\begin{abstract}
Entrepreneurship Development Programme (EDP) is mainly focused on development, promotion and strengthening of micro, cottage and small enterprises with the technical and financial support. The rapid entry and growth of Small Enterprises (SES) has constituted one of the most important aspects of development in Nepal. The Government of Nepal (GON), Department of Cottage and Small Industries (DCSI) and Cottage and Small Industries Development Board (CSIDB) under Ministry of Industry (MOI) are specially responsible for development of SEs. Growth rate of SEs is in increasing trends. it seemed that there is increment of about 332 number of cottage and small industries per year. On the basis of types of ownership of business firms, private firms (Sole trading concern) are increased by 264 each year between the periods of FY 1993/94 to FY 2011/12 i.e. in nineteen year time period. The result shows that 87.6 percent cottage and small industries are operated under private firms. It is seen that most of the entrepreneurs want to be self-employees and / or want to work independently. Out of five development regions, central development region has got highest position in the context of increase number of SEs as well as high increment i.e. 658 in each year. Out of total cottage and small industries, near about half i.e. 47.78 percent industries are conducted in central development region.
\end{abstract}

Key Words: Cottage and small industries, Entrepreneurship Development Programme, Small Enterprise, Trends

\section{Background}

Entrepreneurship Development Programme (EDP) is mainly focused on development, promotion and strengthening of micro, cottage and small enterprises with the technical and financial support. EDP provides various types of services to potential entrepreneurs, existing entrepreneurs/enterprises, and intermediary organizations which are involved in the entrepreneurship development. Entrepreneurship development training, skills development training, entrepreneurial competency development, training for trainers, business start and improvement training, micro enterprise creation, business counseling, production management and productivity improvement, marketing, financial management, business management, business expansion/ growth, business identification and selection, business planning and feasibility study and research etc are major activities of the EDP for enhancement of enterprises. After the signing of an agreement by His Majesty's Government of Nepal with the Ford Foundation on April 28, 1954, the Ford Foundation provided financial as well as technical assistance to Nepal for development of cottage, village and small industries in the country (Shrestha, 1981). It is assumed as a first EDP of Nepal.

Small Business Promotion Project (SBPP) was established on November 14, 1983 with the guidelines and support of the Government of the Federal Republic of Germany. The purpose of establishment is to improve entrepreneurial capabilities in the small business sector of Nepal (Karki, 2013). It was believed that the project will contribute towards increasing income and employment in Nepal's small business sector and create job opportunities. Since 1956, Government of Nepal (GON) commenced to formulate five year national plan. In the context of entrepreneurship development aspects, 
GON has always given emphasis to encourage private sector to invest their savings in industrial sector for increase production volume and sale and create employment opportunities to people (Karki, 2013 $\mathrm{a} \& \mathrm{~b}$ ). It can be seen in several industrial policies such as first industrial policy (during first five year plan); industrial policy of 1974; industrial policy of 1981; industrial policy of 1987; industrial policy of 1992 and industrial policy of 2010.

Entrepreneurship on small scale is the only solution to the problems of unemployment and proper utilization of both human and non-human resources and improving the living conditions of the poor masses (Singh, 2009). Entrepreneurship assumed as means of self employment. Entrepreneurs and entrepreneurial activities have been considered to be important contributors to economic well-being all over the world. The most important contributions of entrepreneurship comprise job creation, smoothing of the markets by introducing innovation, and enhancing efficiency through more competition and poverty reduction by self-employment options (Pfeifer and Sarlija, 2010). Sehgal (2011) stated that entrepreneurship is the ability to start a new enterprise to make more profits by way of producing or marketing goods and services to meet the needs and requirement of customers. Entrepreneurship plays a dominant role in the growth and development of an economy. Small Enterprises (Industries), (SEs) have been operated from long-time in Nepal and played vital role in the context of self-employments, employment generation, utilization of local resources, poverty alleviation, and economic growth of the nations. Most western governments provide encouragement and tax break to those who run small business (Blanchflower and Oswald, 1998). Nepalese government also provides encouragement and tax break to those who run micro and small enterprise (Industrial Policy, 2010 and MOI, 2011). Small scale industries defined as enterprises (industries) other than micro traditional and cottage having investment up to Rs 50 million (MOI, 2011).

Small industries (Manufacturing sector) defined as "more than twenty five lakh but does not exceed five crore rupees and small industry (Service sector) defined as "more than ten lakh rupees but does not exceed two crore rupees" (Indian Gazette, 2006).

Udyog Parishad (Council of Industry), a pioneer organization in the industrial sector in Nepal, was constituted in 1935. It was entrusted, among other things, with the task of developing agriculture, industry and commerce in the country. After a few years, Nepal Kapada Ra Gharelu Illam Prachar Adda (hereafter referred to as the department of Cottage Industries) was established in 1939, which undertook many commendable measures for the growth of small and cottage industries in Nepal. It was structured, restructured and revamped from time to time to make it compatible with the time and situation. In 1992, Department of cottage and Small Industry (DCSI) and Cottage and Small Industry Development Board (CSIDB) were restructured with a view to make them more effective in their roles of industrial promotion, administrative and supportive functions. There are two key government institutions with extensive network throughout the country for the development of the Cottage and Small Industry (CSI) sector and both institutions are engaged in promotional, expansion, strengthening and regulatory activities (IEDI, 1998 \& CSIDB, 2070 B.S.). Out of seventy five districts, DCSI works for twenty seven districts and CSIDB works for forty eight districts.

The rapid entry and growth of Small Enterprises (SEs) has constituted one of the most important aspects of development in post-reform (Democracy) Nepal. There are more than 3,09,775 MSEs in Nepal's industrial sector and they proposed employed about 25,03,437 people and proposed investment Rs. 20,233.904 million till 2012 A.D. (MOI,2069 B.S.). According to Nepal Living Standard Survey 2010/2011, per capital income of Nepalese people is near about \$642 (Rs 41, 659). According to National population census 2011, total population of Nepal is 2,64,94,504 till 22 June, 2011. Most of the people i.e. 83 percent people live in rural area only, 17 percent people live in urban area (CBS, 2012). One 
fourth population i.e. 25.42 percent still live under below poverty line.

The Nepalese economic scenario reveals predominance of the primary sector, slow growth and mass deprivation. With virtually no modern physical infrastructure in a highly congested and difficult terrain, limited exploitable natural resources, small number skilled labour forces, the option for rapid development have been limited and the choices uncertain and limit. The industrial sector is not developed and is only in the form of smaller scale industries (Bajracharya, 2007). It has been witnessed that micro enterprises have become increasingly popular in the new development agenda across the globe and more so in the developing world to address income and employment opportunities. As through the development of micro-enterprise the people in rural areas get income and employment (UNDP, 1998). Bajracharya (2003) had observed that the prevailing policy of the government is not very encouraging to the Micro and Small Enterprises (MSE) Sector. The laws and regulations generally cover only industrial enterprises and do not cover enterprises in other sector. To promote and extend business sector, the government should be able to provide sound business environment such as friendly business environment for investment and their returns, appropriate rules and regulation for security of investment, formulated adequate and appropriate strategies and policies for production of goods and services and their market (Karki, 2011).

This paper tries to highlight some organizations regarding the entrepreneurship development programme in Nepal. It is not enough to explore the EDP in Nepal. It is just about a glance of EDP. This paper tries to study the trends of growth of cottage and small industries in Nepal according to types of registration (ownership) of the industries. The paper also tries to study the development regions according to time. The results of the research is based on the use of simple statistical tools i.e. percentage and fitted time series model. The paper may be useful to researchers, students, academicians, policy-makers and others for the understanding of registration trends of small enterprises (industries) in Nepal. The main objective of the study is to explore entrepreneurship development programme with reference to small enterprises in Nepal. Other objectives of the study are as follows:-

i) To analyze trends of small enterprises development/growth.

ii) To compare growth rate of SEs in different development regions in Nepal

\section{Data and Methods}

The research is based on descriptive cum analytical research approach. The data are collected from secondary sources. Data are collected, specially, through industrial promotion statistics and industrial bulletin published by ministry of industry, department of cottage and small industries(DCSI). The DCSI is one of the major sources data collection and authentic organation for resgistration of small indurstry .Collected data are edited and tabulated required for the research. For analysis of data some statistical tools are used. Percentage and fitted time series model are used for data analysis.

Fitted Times Series Model

$\mathrm{Y}=\mathrm{a}+\mathrm{bt}$ is a linear model

Where, $Y=$ Number of cottage and small industries

$\mathrm{a}=$ Number of SMEs in average per year

$b=$ Number of SMEs on incremental basis per year

$\mathrm{t}=$ Time (in year)

\section{Result and Discussion}

The growth rate scenario of cottage and small industries in Nepal is given in table 1. In Nepal, cottage and small industries (CSIs) are registered under three types of ownership i.e. the first one is private firm. the second one is partnership firm and the third one is Private Company. The table 1 presents the numbers of these three different types of ownership CSIs by Fiscal Year (FY). 


\section{Forms of Cottage and Small Industries in Nepal}

Types of business firms are determined by the rules and regulation of the nation with the limitation of their capital investment and volume of transactions. One of the important things for an entrepreneur is to select an appropriate form of business organization. The amount of capital, risk and control is directly affected by types of forms of the organization. It was found that out of 1,97,264 cottage and small scale industries, $87.6 \%$ were functioning under sole proprietorship, $5.4 \%$ were found under partnership and $7 \%$ were in the form of private limited company. It seems that most of the entrepreneurs have been wanted to operate their businesses independently i.e. under private firms act rather than partnership firms and private limited company act. A study result also revealed that $44.38 \%$ were functioning under sole proprietorship, $51.25 \%$ were found partnership and 4.37 were in the form of Pvt. Ltd. Company in Bihar, India (Jha, 2010). One thing is similar in between these two studies i.e. sole proprietorship business is highly preferred by the entrepreneurs.

Table 1: Forms of Cottage and Small Industries

(FY 2050/051 to 2068/069)/ (FY 1993/094 to 2011/012)

\begin{tabular}{|c|c|c|c|c|c|c|}
\hline $\begin{array}{l}\text { Particulars } \rightarrow \\
\text { Fiscal Year } \downarrow\end{array}$ & $\begin{array}{c}\text { Private } \\
\text { Firms }\end{array}$ & $\begin{array}{l}\text { Partnership } \\
\text { Firm }\end{array}$ & $\begin{array}{l}\text { Private } \\
\text { Limited }\end{array}$ & Total & $\begin{array}{c}\text { Capital } \\
\text { Investment in Rs }\end{array}$ & $\begin{array}{c}\text { Employment } \\
\text { No. }\end{array}$ \\
\hline $2050 / 51$ & 8535 & 630 & 321 & 9486 & 572 & 153000 \\
\hline $2051 / 52$ & 7833 & 439 & 247 & 8519 & 537.64 & 75091 \\
\hline $2052 / 53$ & 8638 & 468 & 544 & 9650 & 722 & 92581 \\
\hline $2053 / 54$ & 7404 & 446 & 346 & 8196 & 604 & 85540 \\
\hline $2054 / 55$ & 8669 & 471 & 481 & 9621 & 881 & 93094 \\
\hline $2055 / 56$ & 8789 & 684 & 533 & 10006 & 962 & 88973 \\
\hline $2056 / 57$ & 8889 & 549 & 685 & 10123 & 1035 & 79618 \\
\hline $2057 / 58$ & 8368 & 407 & 542 & 9317 & 732 & 67975 \\
\hline $2058 / 59$ & 8851 & 526 & 513 & 9890 & 772 & 65374 \\
\hline $2059 / 60$ & 6768 & 454 & 340 & 7562 & 591 & 47455 \\
\hline $2060 / 61$ & 5985 & 548 & 600 & 7133 & 611 & 44725 \\
\hline $2061 / 62$ & 6972 & 499 & 559 & 8030 & 1101 & 74695 \\
\hline $2062 / 63$ & 5864 & 372 & 1994 & 8230 & 670 & 39738 \\
\hline $2063 / 64$ & 7587 & 386 & 738 & 8711 & 782.6 & 54145 \\
\hline $2064 / 65$ & 7993 & 533 & 856 & 9382 & 877 & 54523 \\
\hline $2065 / 66$ & 16238 & 541 & 943 & 17722 & 1531.7 & 82045 \\
\hline $2066 / 67$ & 11250 & 654 & 1116 & 13020 & 1532.88 & 70561 \\
\hline $2067 / 68$ & 12359 & 1145 & 1154 & 14658 & 14750911 & 72918 \\
\hline $2068 / 69$ & 15831 & 952 & 1225 & 18068 & 1727.44 & $\begin{array}{c}\text { Not } \\
\text { Available }\end{array}$ \\
\hline Total Number & 172823 & 10704 & 13737 & 197264 & 3025 & 1417161 \\
\hline Total in Percentage & $87.6 \%$ & $5.4 \%$ & $7 \%$ & 100 & & \\
\hline
\end{tabular}

Fitted time series model in which $\mathrm{Y}$ is number of cottage and small industries and $\mathrm{t}$ is time (in year). In this model, as t (Year time) increased by 1 year, then the total number of cottage and small 
industries increased by 331.879 ( $\approx 332$ number). It means per year there is increment of about 332 numbers of cottage and small industries. Between the time period FY 2050/051 to FY 2068/069 (B.S.) i.e. FY 1993/94 to 2011/12, number of cottage and small industries (CSIs) increased by 332 per year. Whereas, private firms under CSIs, are increased by 263.574 (264). It means per year there is increment of about 264 numbers of private firms under cottage and small industries. In the case of partnership firms under CSIs, they are increased by $9.142(\approx 9$ number $)$ per year. In the case of private limited company under CSIs they are increased by $52.142(\approx 52)$. It seems that private firms reveal highest increment i.e. 264 per year, and followed by private limited and partnership firms. It seems that they believed mostly in their own skills and ability rather than in other people and preferred to be self-employed. International Social Survey Programme (ISSP) data reveal that surprisingly large numbers of people in the industrialized countries say they would prefer to be self-employed. They report to be more satisfied, cetris parbus, than to be employees (Blanchflower and Oswald, 1998). On the basis of fitted time series model, the number of cottage and small industries for the year 2075 B.S. can be forecast. The number will be reach as much as 12,042. It is a symptom of increasing trend of CSIs in Nepal.

\section{Registration Trend of Cottage and Small Industries by Regional}

On the basis of administrative view point, Nepal is divided into five development regions, fourteen zones and seventy five districts. Out of total numbers of cottage and small industries i.e. 1,87,778, the time between FY 2051/52 to FY 2068/69, highest number of industries were established in central development region i.e. 89,721 (47.78 percent) then after 32,813, 32,626, 15,636, and 9,716 in western development region, eastern development region, mid-western development region, and far-western development region respectively.

Table 2: Registration Trend of Business Firms by Regional According to Time (FY 2051/052 to 2068/069 B.S. i.e. FY 1994/095 to 2011/012)

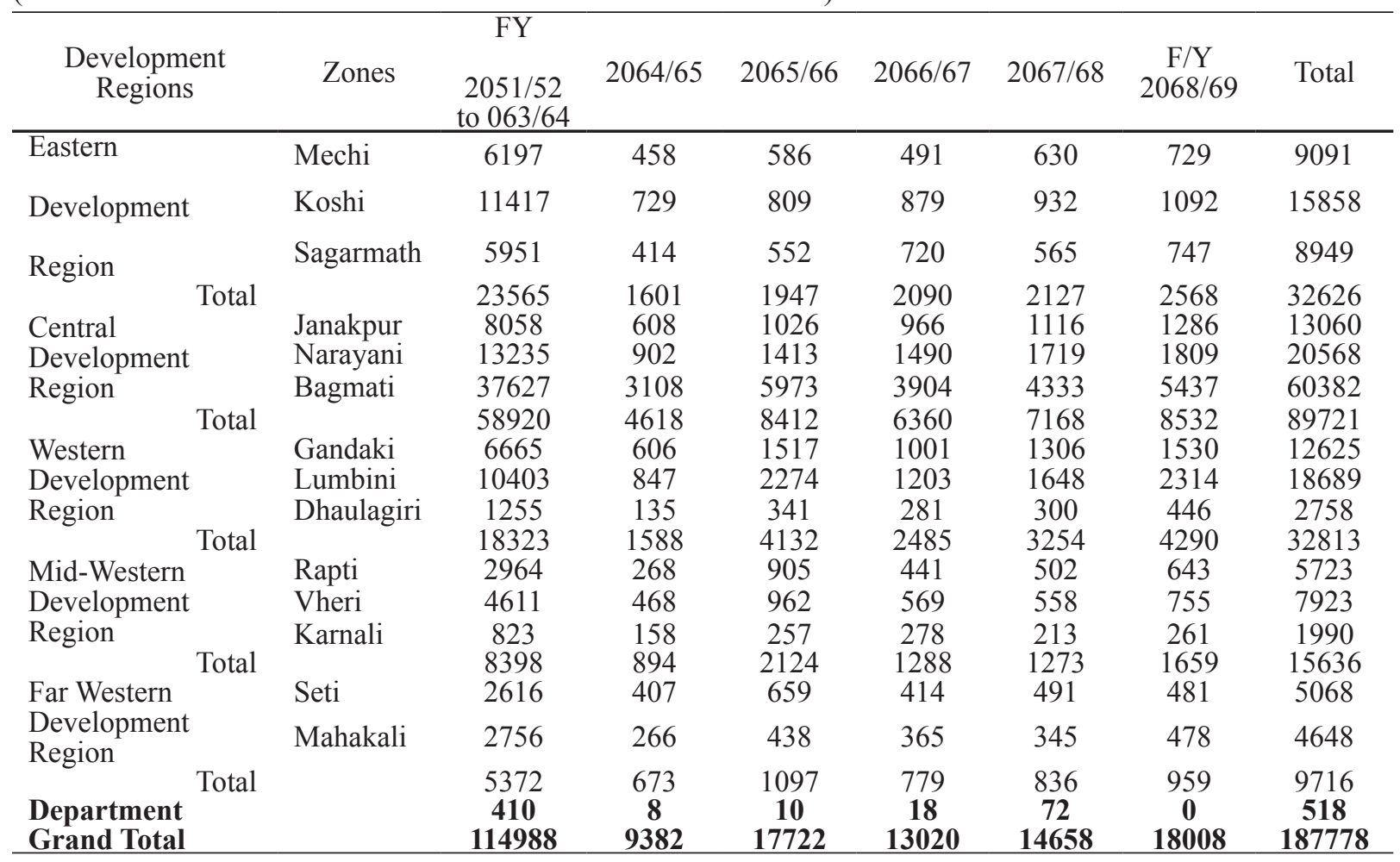


On the basis of fitted time series model, registration trends of cottage and small industries by regions according to time between FY 2064/065 i.e. 2007/08 and FY 2068/069 i.e. 2011/12 there is increment of about $1,418.8(\approx 1419)$ (Table, 2$)$. In the case of development region, there is increment of about $658.4(\approx 658)$ numbers of cottage and small industries in central development region. There is increment of about $211.4(\approx 211)$ in eastern development region. Similarly, there is increment of about $452.6(\approx 453)$ in western development region. There is increment of about $67.9(\approx 68)$ in midwestern development region and increment of about 31 numbers of cottage and small industries in farwestern region. To compare among five development region, central development region has got highest increment ratio and far-western development region has got lowest increment ratio. Capital of the country i.e. Kathmandu, main custom office in the border between Nepal and India (Raxaul) i.e. Birgunj and main Nepal-China custom border i.e. Tatopani-Khasa lay down in central development region and it also seems that comparatively this region has possess adequate infrastructure and physical facilities. It is main reasons behind the highest number of industries in this region.

\section{Conclusion and Suggestion}

Data are taken from department of cottage and small industries and result is based on fitted time series model. The results reveal that the numbers of entrepreneurs and enterprises are in increasing trends. In Nepal, whereabouts most of the people live in rural area and they are highly dependent on traditional agriculture farming for their livelihood. Cottage and small industries are more suitable enterprises to enhance their livelihood and income generation through utilization of local resources, skills, and labour with investing a little capital. The results reveal that most of the businessmen/ entrepreneurs want to conduct their business under private firm. It is seemed that most of the entrepreneurs want to be selfemployees and or want to work independently. An individual skill, capital, resources and ability may be inadequate to operate industry efficiently as well as smoothly. Therefore, it is suggested that people are encourage into limited company or partnership firms. Near about half of the cottage and small industries are conducted in central development region. It is suggested that to balanced in regional development of the country, there is need to give emphasis on established these types of industries in other development region with the aim of proper utilization of all types of resources. For it, government should be able to arranged minimum require infrastructure for establishment of industries in these regions. Entrepreneurship on small scale is the onlyone solution to the problems of unemployment and proper utilization of both human and non-human resources and improving the living conditions of the poor masses (Singh, 2009). For industrial development of the nation, micro and small enterprise might be more appropriate form of enterprise rather than medium and large scale enterprise due to limited resources and inadequate infrastructure, in developing country like Nepal.

\section{Acknowledgment}

I wish to extend my sincere thanks to Janapriya Research and Consultancy Centre (JRCC), Janapriya Multiple Campus, Pokhara for providing me such kind of academic career development opportunity. I would like to thank to my research supervisor Associate Professor Nagendra Kumar Jha, Ph. D, Patna university, Patna, Professor Vikash Kumar KC, Ph.D., and Professor Ramesh Shrestha, Ph. D. for their continuous support in reviewing and suggestion of this paper. 


\section{References}

Australian Embassy, (7 March, 2013). Australian embassy celebrates international women's day 2013. Kathmandu: Australian Embassy

Bajracharya, P. et al., (2003). Integrated Report on MSE-PR, submitted to ILO. Kathmandu, Nepal Bajracharya, P., (2007). Regional development strategy. Kathmandu: ADB-NPC

Bajracharya, P. et al. (2003). Micro and small enterprises policy in Nepal, review of legal and policy framework. Kathmandu:.Submitted to ILO/UNDP

Blanchflower, D.G. and Oswald, Andrew J. (1998). What makes entrepreneurs? Journal of Labour Economics Vol 16 (1). Published by University of Chicago Press.

Canadian Cooperation Office (CCO)-Nepal, (2012). A target evaluation of micro enterprise development programme. Kathmandu: CCO- Nepal

Industrial Enterprises Development Institute (IEDI). (1998). A report on organizational analysis of the department of cottage and small industries and cottage \& small industries development board. Unpublished report supported by small business promotion project (SBPP-GTZ).

Jha, N.K. (2010). Problems and prospects of rural entrepreneurship in Bihar: a case study. Patna University Journal Vol 34 (Annual).

Karki, B.B. (2011). Doing business and role of government for entrepreneurship development. The Journal of Nepalese Business Studies, Vol. VII No. 1 Dec. 2010/2011.

Karki, B.B. (2013). Entrepreneurship development programme in Nepal. Pokhara:Chhunumunu Offset Press

Karki, B.B. (2013). Industrial policies for entrepreneurship development in Nepal. Pokhara: Chhunumunu Offset Press

Ministry of Industry (MOI). (2010). Industrial policy 2010.Kathmandu: MOI

Ministry of Industry (MOI), Department of Cottage and Small Industry (DCSI) (2069 B.S.). Industrial Bulletin, Year 17, Volume 4.

National Planning Commission (NPC) Central Bureau of Statistics (CBS) (2012). National population and housing census 2011 (National Report), Vol. 01, NPHC 2011, Kathmandu:NPC, CBS

Pfeifer, S \& Sarlija, N. (2010). The relationship between entrepreneurial activities, national and regional development and firm efficiency-Global Entrepreneurship Monitor (GEM)-based evidence from Croatia. The Journal of Entrepreneurship, Vol.19 (1) pp 23-41.

Pun, L. (2010). Introduction to micro enterprise development model and its achievement in Nepal, Micro-Enterprise Development for Poverty Alleviation. Vol 1 (MEDEP/ UNDP, Ministry of Industry (MOI).

Sehgal, M.K. (2011). Entrepreneurship development: a systematic approach. New Delhi: UDH Publishers \& distributors Pvt. Ltd

Shrestha, B.P. (1981). An introduction to Nepalese economy. Kathmandu: Ratna Pustak Bhandar

United Nationals Development Programme (UNDP). (1998). Overcoming human poverty.

New York: UNDP Poverty Report.

The Gazette of India (2006). The gazette of India (extraordinary) Part II, Section 3, Sub-section (ii) No. 1152 (Saturday, September 30), New Delhi: By Authority 